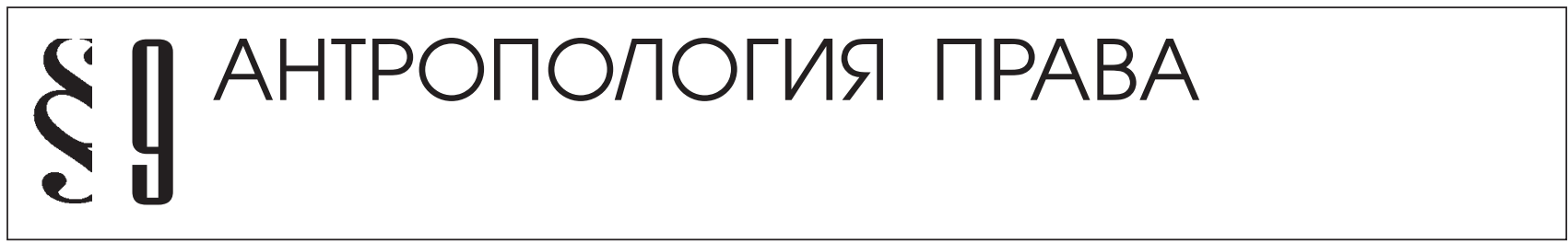

Новиков О.А.

\title{
РЕЛИГИОЗНОЕ ОБОСНОВАНИЕ ПРАВА И ИДЕЯ ПРАВ ЧЕЛОВЕКА
}

\begin{abstract}
Аннотация: Статья посвящена проблеме обоснования позитивного права в категориях религиозной нравственности, а также вопросу о соотношении идеи прав человека, положенной в основу концепции правового реформирования современной российской государственности и традиционных ияенностей Российской иุивилизации. Христианская традиция и опыт восточнохристианской государственности, исторический опыт Византийской империи, России, и других стран Православного Востока говорит о том, что существование государства оправдывается только тогда, когда оно служит определенному идеалу. Исследуется обоснование иенности права в государственно-правовой традиции христианства. Обрашается особое внимание на исторический опыт византийской государственности. Анализируется византийская концепция «симфонии властей». В статье исследуются современные проблемы «мультикультурного» общества Западной Европы. Основное внимание в работе автор акцентирует на необходимости соединения идеи прав человека и нравственных иенностей, а также на необходимости нового обращения к историческому опыту Российской государственности, который свидетельствует о неизменности основных мировоззренческих констант, существовавщих в русском обществе и являвшихся основой государственной идеологии.
\end{abstract}

Ключевые слова: традиция, ценность, идея, религия, православие, государство, право, концепиия, мировоззрение, идеология

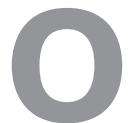

бращение к истокам государственно-правовой традиции всегда является актуальным и позволяет проанализировать основные принципы формирования той или иной правовой системы. Поскольку Россия в известной степени является наследницей Византийской империи в идеолого-политической сфере, то для осознания перспектив современного Российского государства представляется важным раскрытие этого исторического опыта. Говоря же о важности византийского наследия России, стоит отметить, что основную его часть составляет религиозная традиция, в том числе и традиция обоснования права в категориях религиозной нравственности.

С другой стороны, здесь нельзя не отметить тот факт, что настоящее время стало эпохой так называемого «мировоззренческого кризиса». В частности, существует мнение о том, что не стоит искать какую бы то ни было истину, а каждый вполне может сформулировать ее для себя сам, ориентируясь, правда, на некие «общие стандарты». Противоречие подобного подхода состоит в том, что он говорит как раз об «истинности» такого положения. При этом часто не признается легитимность религиозного мировоззрения, и, в частности, в конфликт входит светское и религиозное понимание прав человека. Первое говорит о них как об определенной догме. Согласно же религиозному пониманию, эта категория может считаться только производной от свободы человеческой личности.

Христианская традиция и опыт восточнохристианской государственности, исторический опыт Византийской империи, России, и других стран Православного Востока говорит о том, что существование государства оправдывается только тогда, когда оно служит высшим идеалам - воплощает христианский Закон в своей жизни, или, по крайней мере, стремится к этому. А показателем, критерием такого стремления служит право. Вопрос о ценности права занимает значительное место в современной доктрине Русской Церкви. Так, например, в «Социальной Концепции РПЦ» отмечается: «При судействе- общественном строе, описанном в Книге Судей, - власть действовала не через принуждение, а силой авторитета, причем авторитет этот сообщался Божественной санкцией...»1. Христианский

\footnotetext{
${ }^{1}$ Основы социальной концепции РПЦ // Библиотека Веб-Центра «Омега», 2000. Использованы материалы Официального сайта Русской Православной Церкви [Электронный ресурс]. URL: http: www.sedmitza.ru (дата обращения: 10.04.2013).
} 
идеал власти получил свое выражение в концепции симфонии властей, сформулированной императором Юстинианом (527-565 гг.) в своей VI Новелле: «Есть два величайших блага, дары милости Всевышнего людям священство и царство. Каждое из этих благ, дарованных людям, установлено Богом, имеет свое собственное назначение. Но, исходя из одного и того же начала, оно и проявляется в единении, в совместной деятельности» ${ }^{2}$.

По словам русского философа Л.А. Тихомирова в истории «конкурируют» две мировоззренческие модели, - религия Бога и «религия человека»: «основных религиозно-философских идей, давших исходные пункты миросозерцанию человечества, всего две. С одной стороны, у людей возникает мысль о господстве над миром и всем существующим Высочайшего Сверхтварного Бога... С другой... возникает мысль о самосущности природы, никем не сотворенной» ${ }^{3}$.

В особенности стоит остановиться на второй мировоззренческой модели. Она рассматривает права человека как некую «сверх-идеологию». Это идея либерализма, которая положена в концептуальную основу современного правового реформирования в России. Стоит отметить также и то, что нравственный релятивизм, ставший приметой нашего времени, также является результатом последовательного стремления к воплощению идеи автономии личности, и понимания прав человека в отрыве от нравственного закона.

Предположим, что либерализм (со всем его идейным багажом) есть благо. Это означает, что благом будет и его распространение и развитие. Можно допустить пользу его распространения, но в случае с развитием, иначе говоря, с появлением новых «свобод», представление о его «абсолютной пользе» неизбежно наталкивается на преграду из так называемых «традиционных ценностей» - культурнонравственных правил, которые в значительной степени сформировались под влиянием религиозной традиции.

Власть и общество в нашей стране постепенно начинает осознавать, что ничем не сдерживаемое развитие идеи прав человека может привести негативным последствиям. Так, например, министр иностранных дел России С.Б. Лавров в одном из интервью ответил на вопрос о том, как нашей стране следует развивать отношения с западом, не учитывая отношения в гуманитарной сфере, в том числе серьезные разногласия по поводу понимания демократии, прав и свобод человека, и т.д.: «В универсальном смысле ценности - это то, что заключено во Всеобщей декларации прав человека, которая была принята вскоре после Второй Мировой войны и создания Организации Объединенных

${ }^{2}$ Шмеман А. Исторический путь Православия. - Киев : Пролог, 2003. - C. 205.

${ }^{3}$ Тихомиров Л.А. Религиозно-философские основы истории. - М., 2007. - C.50-51.
Наций. Попытки навешивать на эти универсальные подходы свои дополнительные видения прав человека выходят за рамки универсально признанных ценностей. В конце концов, в других цивилизациях тоже есть свои ценности, которые едва ли приживутся на европейской почве. С учетом подавляющего большинства населения, исповедующего православие или придерживающегося православных традиций, подобные «довески» к универсальным ценностям едва ли дадут какие-то всходы. Они лишь вызывают реакцию отторжения» ${ }^{4}$.

Право является своеобразным инструментом, призванным «вести» общество к определенной цели. По словам И.А. Ильина: «Для того, чтобы сознание человека могло признать право и совершить его духовное приятие - право должно быть обосновано. Обосновать право, значит показать, что оно практически необходимо на пути человека к осуществлению верховного блага» 5 . Будет ли прочным, эффективным, обоснование права, когда «верховным благом» признается сам человек?

В правовой культуре различных стран всегда будет актуальным вопрос о соотношении «права» и «правды»позитивного права и моральных ценностей, разделяемых большинством общества. С одной стороны, они взаимно влияют друг на друга, и под влиянием политической воли законодателя или иных причин, в обществе может утрачиваться совсем или «размываться» ощущение присутствия нравственного закона. Но неспособность его сформулировать вовсе не означает того, что обществом ставится под сомнение факт его существования, сама необходимость существования этого закона. От того, насколько закон, власть соответствуют «правде» общества зависит их легитимность. Если власть ставит выше писаного закона свод неизменных нравственных правил, которые, - и это признается, - нельзя даже при всем желании воспроизвести законодательно, в силу несовершенства самого закона, человека, мира, и т.д., то это приводит укреплению правовой культуры в обществе. В том же случае, если между законом и нравственностью ставится знак равенства, то любые ошибки законодателя влекут и отрицание самого нравственного закона. Последствия такого отрицания ярко иллюстрирует история России последнего столетия. Поэтому закон должен основываться на нравственности, иначе говоря «право» должно соответствовать «правде».

Необходимо отметить, что развитие идеи прав человека и на самом западе приводит к негативным

\footnotetext{
${ }^{4}$ Интервью Министра иностранных дел России С.В.Лаврова радиостанции «Коммерсанть FM», Москва, 20 марта 2012 года [Электронный ресурc]. URL: http://www.mid.ru/brp_4.nsf/newsl ine/5DFA97AF48053E5E442579C700638AE3 (дата обращения: 24.03.12).

${ }^{5}$ Ильин И.А. Общее учение о праве и государстве. - М., 2006. - С. 227.
} 


\section{Право и политика $6(162) \cdot 2013$}

явлениям, которые не остаются незамеченными для определенной части западного общества. Так, 31 августа 2010 года в Германии разгорелся громкий политический скандал, после того как Тило Саррацин - член правления Бундесбанка и известный немецкий политик, презентовал в Берлине свою книгу под названием: «Германия самоликвидируется», в которой озвучил свои идеи о губительности демографической, социальной, миграционной и образовательной политики, на протяжении многих лет проводившейся руководством ФРГ ${ }^{6}$. За выход этой книги Сарацин подвергся критики со стороны ряда политиков Германии, и вынужден был покинуть правление Бундесбанка. Однако уже 17 октября 2010 канцлер Германии Ангела Меркель признала неудачу попыток построить мультикультурное общество в этой стране:

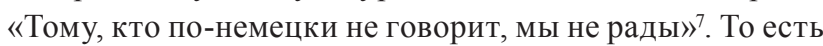
в рамках последовательного осуществления принципов либеральной государственно-правовой модели национальный вопрос оказался неразрешимым.

Каким же образом примирить права человека и традицию? В «Декларации о правах и достоинстве человека», принятой X Всемирным русским народным собором в 2006 году, отмечается: «Мы различаем две свободы: внутреннюю свободу от зла и свободу нравственного выбора. Свобода от зла является самоценной. Свобода же выбора приобретает ценность, а личность достоинство, когда человек выбирает добро. Наоборот, свобода выбора ведет к саморазрушению и наносит урон достоинству человека, когда тот избирает зло. Права человека имеют основанием ценность личности и должны быть направлены на реализацию ее достоинства... Именно поэтому содержание прав человека не может быть не связано с нравственностью» ${ }^{8}$. Таким образом, актуальным в настоящее время представляется вопрос об обосновании права в категориях религиозной нравственности, примеры которого необходимо искать в православной государственно-правовой традиции.

\section{Библиография:}

1. Декларация о правах и достоинстве человека/ Принята Х Всемирным русским народным собором в 2006 г. [Электронный ресурс]. URL: http://www.sedmitza.ru/text/443832.html. (дата обращения: 1.06.11).

2. Ивановский A. Самоликвидация Европы [Электронный ресурc]. URL: http://www.pravoslavie.ru/smi/39035. htm (дата обращения: 18.06.11).

3. Ивановский А. Реабилитация Тило Сарацина? [Электронный ресурc]. URL: http://www.pravoslavie. $\mathrm{ru} / \mathrm{smi} / 42233 . h t m$ (дата обращения: 18.06.11).

4. Ильин И.А. Общее учение о праве и государстве [Текст] / И.А. Ильин. - М. : Хранитель, 2006. - 510 с.

5. Интервью Министра иностранных дел России С.В.Лаврова радиостанции «Коммерсанть FM», Москва, 20 марта 2012 года [Электронный ресурс]. URL:http://www.mid.ru/brp_4.nsf/newsline/5DFA97 AF48053E5E442579C700638AE3 (дата обращения: 24.03.12).

6. Основы социальной концепции РПЦ // Библиотека Веб-Центра «Омега», 2000. Использованы материалы Официального сайта Русской Православной Церкви [Электронный pecypc]. URL: http: www.sedmitza.ru (дата обращения: 10.04.2013).

7. Тихомиров Л.А. Религиозно-философские основы истории [Текст] / Вступ. ст. М. Б. Смолин-М. Фонд ИВ, 2007. - $808 \mathrm{c}$.

8. Шмеман А. Исторический путь Православия [Текст] / А. Шмеман. - Киев : Пролог, 2003. - 414 с.

\section{References (transliteration):}

1. Ivanovskiy A. Samolikvidaciya Evropy [Elektronnyy resurs]. URL: http://www.pravoslavie.ru/smi/39035.htm (data obrascheniya: 18.06.11)

2. Ivanovskiy A. Reabilitaciya Tilo Saracina? [Elektronnyy resurs]. URL: http://www.pravoslavie.ru/smi/42233.htm (data obrascheniya: 18.06.11).

3. Il'in I.A. Obschee uchenie o prave i gosudarstve [Tekst] / I.A. Il'in. - M. : Hranitel', 2006. - 510 s.

4. Tihomirov L.A. Religiozno-filosofskie osnovy istorii [Tekst] / Vstup. st. M. B. Smolin-M. Fond IV, 2007. - 808 s.

5. Shmeman A. Istoricheskiy put' Pravoslaviya [Tekst] / A. Shmeman. - Kiev : Prolog, 2003. - 414 s.

\footnotetext{
${ }^{6}$ Ивановский A. Самоликвидация Европы [Электронный ресурс]. URL: http://www.pravoslavie.ru/smi/39035.htm (дата обращения: 18.06.11).

${ }^{7}$ Ивановский А. Реабилитация Тило Сарацина? [Электронный pecypc]. URL: http://www.pravoslavie.ru/smi/42233.htm (дата обращения: 18.06.11).

${ }^{8}$ Декларация о правах и достоинстве человека / Принята X Всемирным русским народным собором в 2006 г. [Электронный pecypc]. URL: http://www.sedmitza.ru/text/443832.html. (дата обращения: 1.06.11).
} 